MAN'S IMPACT ON THE ENVIRONMENT

P.A.J. Ryke, Bureau for Research, PU for CHE

\title{
OPSOMMING
}

Die mens se verhouding tot sy omgewing nader in baie dele van die wereld ' $n$ kritieke stadium, want die veranderinge wat plaasvind, kan onomkeerbaar wees en onvoorsiene, verreikende gevolge hê. Baie van hierdie omgewingsversteurings begunstig die korttermynvermeerdering van mensgetalle, maar dit het langtermynnadele ten opsigte van oorlewing. Hoe meer gesofistikeerd die landbou word, hoe groter is die versteuring van natuurlike ekostelsels en hoe groter is die persentasie van die energievloei binne die stelsel wat vir menslike gebruik ingespan word. Nieteenstaande die sogenaamde Groen Revolusie is die per capita produksie van grane in die Derde Wèreld tans onderkant die vlak wat dit 25 jaar gelede was. Gronderosie speel ook 'n belangrike negatiewe rol in verskillende dele van die wèreld en die toenemende gebruik van kunsmis het 'n nadelige effek op grondchemie.

Die snel toenemende mensbevolkingsgetalle baar sorg omdat die dravermoë van die aarde in baie dele van die wèreld reeds ' $n$ maksimumperk bereik het. Die invloed van 'n hoë bevolkingsdigtheid en daarmee gepaardgaande industrialisasie, het ook 'n vernietigingsrol ten opsigte van plant- en dierverskeidenheid gespeel. Daadwerklike pogings word egter in baie lande aangewend om die verdere uitsterwing van spesies te verhoed en die indringing van vreemde spesies te beperk.

Die probleme wat met te veel koolstofdioksied in die atınosfeer en te min osoon in die stratosfeer gepaard gaan, verg ook aandag; dieselfde geld vir die suurreën wat hoofsaaklik as gevolg van die verbranding van fossielbrandstowwe ontstaan. Die behoud van varswatergehalte wat deur verskillende tipes besoedeling bedreig word, is veral in lande soos Suid-Afrika van die allergrootste belang. In die oseane is oliebesoedeling een van die grootste probleme. Op land speel die toediening van plaagbeheermiddels 'n noodsaaklike rol, maar sekere nie-biodegradeerbare gifstowwe hou groot gevare in vir die gesondheid van die mens. 
Omgewingsbeskerming is in taak wat vir elke instansie en individu in hoë prioriteit moet wees. Dit kan slegs deur 'n omgewingsetiek bewerkstellig word wat 'n verantwoordelikheid teenoor die Skepper en sy natuur ten grondslag het. Die mens moet dus rekenskap van sy rentineersterskap ten opsigte van die natuur kan gee - iets wat hy in die verlede nie altyd nagekom het nie.

Ecologically the environment is the "sum of all external conditions and influences affecting the life, developinent and survival of organisms. Living organisıns do not exist under natural conditions in physical and biological isolation, but there is an interplay both anong the various populations themselvos and with the physical and chemical components of the environment. The functional system that results from the interplay - the ecosysten - is a living complex of interloching processes characterized by many cause-effect pathways.

Many of the natural environments of the world have been greatly altered by the activities of people. Forests, for example, have been cut down or burned, swamps have been drained, pasturelands have been overgrazed, fertile soils have become eroded, fields have been planted to cultivate crops, oceans, rivers and dams have become polluted by sewage and industrial wastes, native species of plants and animals have been rediced in numbers or locally exterminated, foreign species have been introduced, and extensive areas of productive land are covered by roads and towns.

Man's relationship with his environment may be approaching a critical stage whereby the changes he makes may be irreversible or may lead to farranging and unforseen alterations. Every invention of man has made his environment more favourable for his short-tern multiplication, but it has made his environment less favourable for his long-term survival. Man depends on nature but the supply of wiat nature offers him is lim. ited. He uses up nature in proportion to his numbers but some men use up nature faster than others. Some employ nature more wisely than others, preferring the distant future to the inmediate future. Some, for this reason, give more in return to nature and to minkind. What has happened in the past shows us that all these factors must influence our 
judgement in deciding how man will have to make his reckoning with nature in the future.

Against this background of increasing concern over the quality of the environment, the disruption of the earth's natural ecosystems, and the depletion of natural resources, there is a growing lobby of opinion that enlightened management of the environment is necessary so that future generations can enjoy a stable biosphere. Pollution, ecology and environment have been projected from the cloistered world of science into the forefront of public debate, and all aspects of man's use of his environment have been widely discussed, often with "passionate interest" (Park, 1981).

The needs and the wants of mankind are brought into clearer perspective with the growth of scientific knowledge and technology. Such developments as the discovery and application of nuclear power, the exploration of outer space, the search for greater knowledge of the resources of oceans and the control of human disease add to, rather than supplant, what people want out of life and what they need for survival. The total impact of man on his environment is caused by his two main socio-economic activities: agriculture (rural life) and industry (urban life). In the final analysis, our well-being in all aspects of life - physical, inspirational, social and economic - depends upon the balance of nature. A central purpose of our lives, therefore, and one affecting all individual and group action, must be the safeguarding of our terrestrial habitat, the biosphere, the earth, the water and the air.

\section{THE AGRICULTURAL ENVIRONMENT AND FOOD RESOURCES}

The biosphere (ecosphere) and, therefore, all living things are a product of the interaction of solar energy with the earth's surface. Under natural conditions, dynamic balances evolve attaining maximum biomass production compatible with the particular environment. The natural cycles of energy and mass function largely as closed systems as plant nutrients are retained within the soil-vegetation system. Agriculture deliberately upsets this balance with the intention of manipulating certain aspects in order to produce the maximum yield of selected foodstuffs suited to man. The consequences are that the maturity of the ecosystem is reduced, and in 
effect it is reduced to a lower developmental level. The diversity of animal and plant species is greatly reduced as is the variety of soil types. Hence the complex interlocking cycles of life-support systems are simplified and short circuited. The most extreme exanple of this effect is the conversion of the vastly complex ecosystem of the tropical forest into monoculture plantations or ranches (Power \&. Follet, 1987). The more sophisticated the form of agriculture, the more distorted become natural ecosystems and the greater the proportion of the energy flow within the system that is bled off for human use (Drew, 1983).

Whatever the origins of agriculture, there can be no doubt that once cultivated plants and domestic animals had been developed, their use spread rapidly. The pattern of permarient settlement was already laid down, social contacts had been established through exogamous mating, and knowledge of the techniques of this major new culture could disseminate quickly. In the two millennia from 9000 to $7000 \mathrm{BP}$, neolithic agricultural cultures became widespread throughout the Middle East, and especially in the valleys of the Tigris and the Euphrates, and across the Sinai Pininsula in the Nile delta.

The history of agriculture following the domesticatien of animals and plants is filled with technological advances of varying importance, each of which has increased the earth's population-sustaining capacity. A few stand out: the discovery of irrigation, the harnessing of animals for draft purposes, the exchange of crops between the Old and New World, the development of mechanical power, and the advances in soil chemistry and plant genetics.

\section{The world food supply}

Since the discovery of agriculture, man's capacity to increase food production has grown several hundred fold, enabling him to sustain a human population today of five thousand million in contrast to the 10 million limit on his numbers set by the hunting econony. In the late 1960 's a breakthrough in food production occurred in the poor countries that improved the prospects for feeding the increasing numbers of people predicted for the future. The main impetus for this agricultural breakthrough, popularly called the Green Revolution, was the successful 
introduction and rapid diffusion of new high-yielding varieties of wheat and rice in several of the larger poor countries: India, Pakistan, the Philippines, Indonesia, Turkey and Mexico, for example (Brown \& Finsterbusch, 1971).

During the first few years the Green Revolution had a pronounced impact on per capita cereal production in several countries, but it was limited to those areas with an adequate, controlled water supply and countries with an adequate marketing system. Despite this agricultural revolution the per capita production of grains in the Third World has fallen below the level it was between 1961 and 1965. We are not headed for famine anymore, we are there (Gortz, 1980). During the last decade many millions of people died of malnutrition or hunger. The reality of the population problems is best illustrated by two extreme examples: the Sahel and Bangladesh. The famine in the Sahel, which has numerous causes - climatic, political, social - would never have grown to such proportions if the pasturelands at the borders of the Sahara had not been overgrazed as a result of the increase in the nomad populations. Once the vegetation was stripped from the land, the Sahara began to nibble away at it, moving south at a speed of 9 to $50 \mathrm{~km}$ a year. Retreating as the desert advances, the nomads and their flocks have created devastating pressure on new areas.

In Bangladesh, similarly, the catastrophe's causes are not simply natural ones. On the contrary, for the past 30 years - as a result not only of population pressure, but also as an effect of the Green Revolution - the foothills of the Himalayas have been subjected to intensive deforestation. The ground cannot hold the rains anymore, so the run-off carries the land away, and the Ganges and the Brahmaputra rivers unexpectedly flood because their beds are higher. This is the main cause of the catastrophic floods of the last decade. A unified plan is necessary, primarily a plan of reforestation comparable to what China has carried out for the past 30 years. Family planning will not be enough, even though it is indispensible if Bangladesh is not to perish well before reaching the 220 million mark - three times the current number - that demographers predict for the year 2000. 
Agronomists have no trcuble pointing out inconsistency when technocrats speak of extending the mechanized, chemicalized ayrieulture all over the globe. A few figurcs will give an idea of the dilemrna. It took modern agriculture only 70 years - from 1882 to 1952 - to destroy half the topsoil of $38,5 \%$ of all cultivated land. During this period the amount of land which could no longer be cultivated increased by 3,45 billion acres. More than a third of the forests that were standing in 1882 have been razed, that is, 4,75 billion acres. Of the three billion acres currentiy under cultivation there are only 1,25 billion acres left of "good land".

The history of attempts at large-scale agricultural modernization in tropical Africa, for instance, is studded with spectacular failures. One of the best-known of these was the groundnuts scheme in Tanzania. The intention was to produce annually about 600000 tens of groundnuts from 1,5 million liectares of previously largely uncultivated savanna in three parts of Tanzania. Originally, in 1947, a sum of 25 milion pounds sterling was allocated for the project, but the difficulties were such that by 1951, when the scheme was abandoned, the cost had risen to 37 million pounds. Probleins were encountered with land clearing and cultivation, with low rainfall, with disease and so on. The money was largely wasted, and the product of greatest value was the realization that such schemes require much more careful planning, which should iriclude consideration of ecological potential. If a mechanized scheme fails, the effect are longlasting because the complete removal of woody plant: will greatly slow down the recovery of the soil and the establishment of a woody fallow.

Current methods of agriculture are even insre destructive than the methods used during that 70 year period. The high per acre yields in the Western countries are obtained at the price of increasing the expenditure of energy, and the disturbance of the water, nitrogen, and carbon cycles, which is untenable in the long run. There are water shortages everywhere. The dilemma was further aggravated by the energy crises. The Grcen Revolution has actually only been possible in industrialized countries by sharply raising the inputs of fossil fuel, which is limited and irreplaceable. The special new seeds, which were supposed to triple the per acre yields are fragile types that require a synthetic environment in order to thrive. This environment is created at the expenditure of an energy equivalent to 500 gallons of oil per acre per year. 
This explains the failure of the Green Revolution in the Third World. Only the rich farmer could afford the fertilizers, insecticides, machinery and irrigation that the new seeds require. Hence the acceleration of the flight from the land and the rise in unemployment (Gortz, 1980). By the beginning of the 1970's the Green Revolution in India had produced a $50 \%$ increase in the grain harvest. However, $40^{\circ}$ of the increase came from the seeding of new areas, a large part of which had previously been used for growing leguminous plants such as lentils or beans - which are the main source of protein for the Indians. On balance: Indians today do not have more grain per capita than 15 to 20 years ago, but their leguminous allotment has dropped by $30 \%$ (Pimental, 1973). That's not all. After several years in which new wells were drilled and electric water pumps installed, the drop in the level of ground water brought about disastrous (and predictable) droughts in many regions of India.

A shortage of nitrogen fertilizer, which is indispensable to the new varieties of grain is another disaster. It takes three tons of oil to produce one ton of fertilizer. India is no more in a position to pay for the fertilizer. Japan has been selling her, nor even to buy the oil necessary to run even half her fertilizer factories. The leap forward of agricultural production to beyond its ecological limits is thus colliding with the energy problem. If the whole world were to use USA agricultural methods on all the land currently under cultivation, agriculture alone would use up the known oil reserves in a matter of 30 years.

The agricultural industry in South Africa is capable of much greater height of productivity than those hitherto reached, and careful-planning by agricultural scientists for boosting production is continually being undertaken. But is would be unrealistic to believe that production can be expanded indefinitely to keep pace with an uncontrolled population growth (Baker, 1976; Fuggle \& Rabie, 1983; Hugo $\varepsilon$ Van Schalkwyk, 1987).

Soils

It is undoubtedly true that manipulation of the soil is one of the most significant ways in which man changes his environment, and one in which he has had some of the most detrimental effects. Three great problems 
challenge the thinking and the energy of those who use the land and the wider circle of people who live from the products of the land. The first is how to control erosion or keep the soil in place, the second is how to maintain the nutrient materials in the soil, and the third is how to bring about understanding and action on the part of those who control the soil resources of the country. The soils of an area represent in many ways a summary, a distillation of all the factors of the environment, human and otherwise, in a locality (Drew, 1983). The importance of soils to man as the basis of agriculture is obvious, but their pivotal point in the enviromment as a whole is apparent from the many references to soils when dealing with other aspects of the environment.

One of the most visible human-induced changes in the landscapes of Africa is the great loss of soil over thousands of square kilometres. To create conditions that allow partial or total erosion is man's most negative impact on soil. Catastrophic soil erosion is most conmon in delicately balanced environments (semi-arid or mountain. in particular) and where the soil is easily erodible. However, physical and chemical soil degradation is much more widespread, and even carefully managed arable agriculture will increase soil losses 5 to $\mathbf{5 0}$-fold compared with losses under a natural vegetation cover.

No region in Africa is free of soil erosion induced by human use of the land. However, sone regions have been more seriously affected than others; these include Uganda, Kenya, Tanzania, Botswana and Lesotho (Bennett, 1975). The chief causes are cropping on too short a fallow period and too many domestic animals on the available land. This subject is emotionally charged and has many political nuances, because some of the conditions arose during the colonial period, when Africans were kept on so-called native reserves. As human population grew in some of these reserves, the traditional ecological ways of life became unsuitable, with the resulting destruction of soil cover. Colonial cfficials prevented the once nomadic peoples from wandering over the territories they had occupied seasonally. The result was that a greatly increased number of animals had less and less land available for grazing. In addition, the remaining grazing lands were all to often ecologically marginal, the better expanses having been preempted by Europeans. 
South Africa's climate and topography make its soils particularly vulnerable to soil erosion. The reliability of rainfall over the greater part of the country is low, evaporation is high, and drought is a common occurrence. A disproportionate percentage of the total precipitation frequently occurs in torrential thunderstorms, which are conducive to high runoff. Quick runoff is also stimulated by the high elevation of the southern African subcontinent. In fact, topography plays a greater role than climate in the development of soil erosion (Rabie $\varepsilon$ Theron, 1983). It has been calculated that erosion has already destroyed more that 25 per cent of the original soil fertility reserves of South Africa.

Loss of valuable topsoil in South Africa is particularly distressing in view of the fact that only 10 to 12 per cent of the land surface is at present under cultivation. It appears unlikely, moreover, that the cultivated area will ever exceed 15 per cent of the land available to agriculture (Schoeman $\varepsilon$ Scotney, 1987). And it must be realised that this loss is, for all practical purposes, irretrievable since it would take nature between 2000 and 7000 years to produce a 17 to $20 \mathrm{~cm}$ layer of soil which is required for cultivation (Rabie \& Theron, 1983).

Although there are many techniques available for attempting to reduce the intensity of erosion it still appears to remain intractible (Goudie, 1981). Despite the billions spent on it the problem persists; this can be attributed at least in part to the fact that, in the calculation of many farmers, the hope of maximizing short-term crop yields and profits has taken precedence over the longer term advantages of conserving the soil. For even where the loss of topsoil has begun to reduce the land's natural fertility and productivity, the effect is often masked by the positive response to heavy application of fertilizer and pesticides, which keep crop yields relatively high (Carter, 1977).

Although construction, urbanization, mining and other such activities are often significant in accelerating erosion of the soil, the prime causes are deforestation and agriculture. In many parts of the world soil erosion on agricultural land operates at a rate which is approximately eight times quicker than topsoil is formed. One serious consequence of accelerated erosion is the sedimentation that takes place in reservoirs, thereby shortening their lives and reducing their capacity. Many dams, especially -448 - 
in semi-arid areas, appear to have an expected life of only 30 years or even less (Rapp et al., 1972).

The most famous case of soil erosion by deflation was the so-called Dust Bowl of the 1930's in the USA (Goudie, 1981). In part this was caused by a series of hot, dry years which depleted the vegetation cover and made the soils dry enough to be susceptible to wind erosion. However, the situation created by this drought was gravely exacerbated by years of over-grazing and unsatisfactory farming techniques. Perhaps the prime cause of this event was the rapid expansion of wheat cultivation in the Great Plains. The number of cuitivated hectares doubled during the First World War as tractors rolled out onto the Plains by the thousands. After the war the wheat cultivation went on apace, helped by the development of the combine harvester, and government assistance. The farmer, busy sowing wheat and reaping gold, could foresee no end to his land of milk and honev, but the vears of favourable climate were not to last and over large areas the tough sod which exasperated the earlier homesteaders had given way to friable soils of high erosion potential. Drought, acting on damaged soils, created the so-called black blizzards, described by Caffey (1978) as follows:

"There was something fantastic about a dust cloud that covered 1,35 million square iniles, stood three miles high and stretched from Canada to Texas, from Montana to Ohio - a cloud so colossal it obliterated the sky. A four-day storm in May 1934 ... transported some 300 million tons of dirt 1500 miles, darkened New York, Baltimore and Washington for five hours, and diopped dust not only on the President's desk in the White House, but also on the decks of ships some 300 miles out in the Atlantic. Masses of dust began to billow into huge tumbling clouds ebony black at the base and muddy tan at the top, some so saturated with dust particles that ducks and geese caught in flight, suffocated; some turning the sky so black that chickens, thinking it night, would roost. Oklahoma counted 102 storms in the span of one year; North Dakota reported 300 in eight months."

Chemical change. 
If fertilizers are applied over a long period of time, the chemistry of soil becomes greatly simplified, its store of nutrients being heavily biased towards calcium, phosphorus and potassium. Other cationic elements are displaced from storage and leached out of the soil by rain water. In turn, this can help to create changes in soil structure. Soils with a high salt content (salts of potassium, sodium, magnesium and calcium) or high alkalinity are characteristic of arid and semi-arid regions. Soils in such areas may be potentially fertile, irrigation being the key to their exploitation. However, irrigation can be used or misused: it can be used to desalinate soils, but it may also cause salinisation of previously fertile soils.

Although careful management allows soils to be irrigated for hundreds of years, in the past salininsation has been an almost inevitible long-term consequence. The gradual increase in salt content of the soils of the Fertile Crescent in Mesopotamia - the cradle of agriculture - can be inferred from the progressively higher salt content of the bricks used for house building in the area over the centuries. The destruction of their farmland by salinisation may have been one of the reasons for the collapse of this and other ancient civilisations of the semi-arid world (Pearce, 1987a).

One consequence of the evaporative concentration of salts, and the pumping of saline waters back into rivers and irrigation canals is that river waters leading from irrigation areas show higher levels of particularly nitrates which can create problems in terms of human consumption. A further problem is that as irrigation water is concentrated by evapotranspiration, the calcium and magnesium tend to precipitate as carbonates, leaving sodium ions dominant in the soil solution. The sodium ions tend to be adsorbed by colloidal clay particles, deflocculating them and leaving the resultant structureless soil almost impermeable to water and unfavourable to root development. The death of vegetaion in areas of saline patches, due to poor soil structure, toxicity and its effect on osmotic pressures creates bare ground which becomes a focal point for erosion by wind and water.

WORLO POPULATION GROWTH 
The world population in 1650 was about 500 million and it doubled over the next 200 years. It took only 80 years from 1850 to 1930 to double again and 57 years to reach a world population of about 5000 million people in 1987. Projections of world population growth are that the next doubling will be between the years 2000 and 2025, at present rates of increase of about 2 per cent per annum. What happens beyond that time is highly speculative but there is little doubt that the carrying capacity of this planet will be reached or exceeded withın the lifetimes of children currently being born. The major difficulty in forecasting world population trends is the differences in the growth rate of populations in different parts of the world and changes in birth and death rates which can occur over quite short periods of time. The more developed areas of the world at present have a growth rate of less than 1 per cent, equivalent to a doubling time of 100 years or more, while less developed countries have growth rates of more than 2,5 per cent and will double in less than 30 years; in Southern Africa the annual growth rate is approximately 2,8 per cent.

The reasons for both the rapid increase in world populations and the lower growth rates in the developed countries are complex. An important factor is the fact that agriculture became energy subsidised instead of labour intensive; fertilizers improved both yield and quality of crops. Human welfare was improved by education, medicines, higher standard of hygiene and nutrition. The life expectancy at birth increased by 40 per cent between 1950 and 1975 in the developing world, by a further 12 per cent in the developed world and by 35 per cent in the world as a whole.

Thus the gains in living standards made in the industrialised countries during the nineteenth and twentieth centuries are now being made in developing countries. Against this pattern of feclining death rates, the birth rates in most developing countries have remained comparatively constant and the populations have grown. The age structure develops a distinct pyramidal structure which points to continued rapid population growth as the juvenile cohorts move through the reproductive age. For instance, in Mexico 46 per cent of the female population is below 15 years of age, the population growth is 3,4 per cent per anrum and will double 
in 20 years. In the majority of developed countries, however, birth rates have declined.

European countries 150 years ago had high birth and death rates but at the turn of the nineteenth century the annual death rate fell from about $40 / 1000$ to $10 / 1000$. Some 50 years later the birth rate declined from $40-50 / 1000$ to around $13 / 1000$. The reason for this is a change in human fertility rather than fecundity. Fecundity is the child bearing potential of a woman: a rate of one birth per 9-11 months over the child-bearing years of 15 to 50 . Fertility is the actual number of children born. In the developed countries the trend towards later marriages (associated with longer periods of education and/or employment of women) and smaller numbers of children (facilitated by contraception) has stabilised the age structure and population growth (Odum, 1971).

There are some signs that the rate of world population growth has slackened since 1970. This is attributed to four factors: The unexpectedly successful result of China's population policies, a significant decline in lowering birth rates of almost all developed countries, some success in lowering birth rates in some less developed countries, and a rise in death rates in several countries, particularly in South Asia and parts of Africa (caused primarily by food shortages during famines caused by droughts and other factors).

The common factors in the less developed countries which are undergoing a demographic transition (including Taiwan, Egypt, Chile, South Korea, Cuba and Southern Africa) seem to be that the majority of people have experienced an increase in social welfare (literacy, health care, reduced infant mortality and better diets) in spite of the fact that some of these countries are still very poor. If this encouraging trend spread to other developing countries, the world could stabilise around 6 milliard but the extent to which this reduced growth is caused by a rise in death rates is a tragic cause for continued concern over world population growth in relation to food resources. It is sometimes difficult to say whether certain of the less developed countries are overpopulated because they are underdeveloped, or underdeveloped because they are overpopulated. 
The problems of providing for an expanding propulation and meeting demands for social justice in South Africa are complex, more complex than analysis by present-day methors of systems analysis or other scientific, sucial or technological tools allows. In man-environnent relationships everything and everyone are all interrelated so it is necessary to move away from simplistic linear thinking to cyclic cybernetic thinking that is harmonious with the natural processes which sustain life. The problems facing South Africa because of population growth, the need for social justice, and their consequent demands on the natural resource base will not be solved by politicians, businessmen, scientists or erigineers working independently of one another; co-ordinated multidisc:plinary approaches to planning for the future will be required (Fuggle, 1933).

\section{PLANTS AND ANIMALS}

Man has probably had a greater influence on plant life than on any of the other components of his environment. Through the changes he has brought about in plant cover he has modified soils, influenced climates, affected geomorphic processes and changed the quality and quantity of some natural waters (Goudie, 1981). Indeed the nature of whole landscapes has been transformed by man-induced vegetation change. The impact of preagricultural folk on the vegetation was probably local and dependent on the population size and how they used fire.

Pressured by increases in the population sizes of hurnanity, a wave of extinction of plants and animals is under way which will cause some half million of the world's ten million species to become extinct in the next few decades. South Africa is one of the countries where rates of extinction have become much higher than the rate of replacement by similar forms through natural evolution (Hall \& Rabie, 1983). There is now a total of 2373 seed-plants and ferns in southern Africa which are either critically rare or in hazard of extinction. This is $12 \%$ of the total of 20044 plants in the region south of Angola, Zimbabwe and Mozambique. Threatened plants are seldom made extinct by direct destruction; usually the cause is the loss of some essential features cif their habitat. The lists of plants in hazard in South Africa are the iymptons of widespread, critical changes to habitats. This has caused populations of once common plants to vanish. 


\section{Deforestation}

Forests have always been a major resource for wood for homes, furniture, fuel, and paper; bark for waterproofing material; nuts, fruits and sugar for food; and land for grazing livestock.

In recent years, forests have become recognized as important recreational resources for camping, hiking, fishing, or just enjoying the view. We have discovered forest lands to be part of water sheds which release water slowly and prevent flooding as well as areas that contain energy fuels and minerals (Purdom $\varepsilon$ Anderson, 1983). Therefore, improper forest management can have wide implications.

The deliberate removal of forest is one of the long-continued and most significant of ways in which man has modified his environment, whether achieved by fire or by cutting. The Phoenicians were exporting cedars as early as 4600 years ago both to the Pharaohs and to Mesopotamia (Mikesell, 1969). The great phase of deforestation in central and western Europe occurred from AD1050 onwards for about 200 years; the landscape of Europe was transformed, just as that of North America, Australia, New Zealand and South Africa was to be as a result of the European expansion, especially in the nineteenth century. Forest clearance for agriculture in the equatorial rain forests has been going on since at least $3000 \mathrm{BP}$ in Africa, $7000 \mathrm{BP}$ in South and Central America and possibly since 9000 BP or earlier in India and New Guinea (Flenley, 1979).

One of the great phases of forest clearance occurring at the present time is that in the humid tropics. The yearly regression rate for the world's tropical moist forests is about 11 million hectares per year. For instance, the Ivory Coast's forests, one of the world's principal sources of tropical hardwoods, now cover one million hectares; in 1965, they covered 15 million hectares (Bourke, 1987). West Africa has lost approximately $80^{2}$ of its moist forests and Southern Asia 703. This is potentially extremely serious because these forests are "a source-book of potential foods, drinks, medicines, contraceptives, abortifacients, gums, resins, scents, colourants, specific pesticides, and so on" (Poore, 1976). Their removal may also create laterization, climatic change and increased rates of erosion. 
Some traditional socinties have developed means of exploiting the rain forest environment which tend to minimize the problems posed by soil fertility deterioration, soil erosion, and vegetation degradating. Such a system is shifting agriculture (swiddens). This harmonious relationship with nature was, for instance, practised by small groups of people living at a mesolithic or neolithic level of culture in the Amazon basin (Ainazonia). These tribes are highly adapted to their environment, bending with it rather than seeking to dominate. The swiddens are forest clearings, usually made by burning, that are cultivated for a few years and then abandoned. The clearings will revert to rainforest provided that they are not too large and provided that the soil has not been exposed to direct sunlight for too lorig a period. It may take 100 years for a clearing to fully revegetate.

In ecological ternıs, the most distinctive positive characteristic of swidden agriculture is that it is integrated into and, when genuinely adoptive, maintains the general structure of the preexisting natural ecosystem into which it is projected, rather than creating and sustaining one organized along novel lines and displaying novel dynamics (Geerts, 1963). The tropical rain forest and the swidden plots have certain common characteristics. Both are close cover systems, in part because in swidden some trees are left standing, in part because some tree crops (such as banana, papaya, areca et cetera) are planted, but also because food plants are not planted in an open field, crop-row manner, but helter-skelter in a tightly woven, dense totanical fabric - a sort of miniaturized tropical forest. Swidden agriculture also involves a wide range of plants, thereby having a high diversity index like the rain forest itself. Thirdly, both swidden plots and the rain forest have high quantities of nutrients locked up in the biotic community compared to that in the soil.

This pattern of land use began to change when colonists first penetrated Amazunia in the 19th century. The major impact, however, has come much more recently with systematic exploitation of the region for timber and agriculture land (Dicksom, 1978). The culture of the people is being changed from neolithic to modern in an instant. Environmentally, one of the world's most tragile and important zones is being subjected to apparently irresistible technological pressure in what is probably the greatest single landscape transformation that man has yet carried out. 
The tropical rain forests have the greatest input of solar energy of any climatic zone; they have abundant yearround rainfall. They are the most productive terrestrial ecosystem on earth with an immensely complicated system of balances between the large number of plant and animal species. A very high proportion of nutrients are stored in the vegetation rather than in the soil and the recycling system is almost closed. Indeed, some of the nutrient cycling is quite independent of the soil. The luxuriant vegetation creates an illusion of fertility in the soil; but nowhere else on earth is the relationship between vegetation and soil so weak. The microclimate created by the forest is also very important. Annual rainfall of $1800-3500 \mathrm{~mm}$ and temperatures consistently in excess of $30^{\circ} \mathrm{C}$ would rapidly convert the soil into a sterile laterite if the vegetation cover did not exist. Deforestation in these areas exposes the soil to direct sun over large areas and also removes the greater part of the area's nutrient store. Predictably, the results are dramatic (Drew, 1983). Extensive forest clearance in Amazonia began at the turn of the century in eastern Brazil. Within a few years much of the land had been abandoned because the loss of nutrients by intense leaching is very rapid. Soil fertility may decline by as much as 80 per cent within a few years. Today it is an area of poverty and economic and social stagnation, covered in a scanty secondary scrub vegetation. Amazonia represents man's first, and perhaps last, real chance to develop a vast land area using an ecologically as well as an economically based developmental model (Simon, 1986).

Possible consequences of deforestation, though also the most speculative, concern changes in the atmosphere. Complete loss of forest and its replacement by scrub would probably increase $\mathrm{CO}_{2}$ levels by up to 10 per cent and oxygen output to the atmosphere would lessen. It does not seem likely that either effect would be very significant on a global scale. More important would be the change in albedo (reflectivity) that would result from such a change in vegetation cover. The forests reflect back $c .7$ per cent of solar energy, whereas a barren scrubland would reflect c. 25 per cent. A computer study suggests that the surface cooling that would occur, together with decreased evaporation, would lessen the upward rise of air in equatorial regions and so cause cooling in the mid and upper troposphere and with steeper lapse rates prevailing. The model predicts 1,5-2,5 per cent more precipitation between latitudes $5-28^{\circ}$ north and $-456-$ 
south, and less precipitation (due to the weakened convection) between latitudes $45^{\circ}-85^{\circ}$ north and $40^{\circ}-60^{\circ}$ south. Drew (1983) states that these ideas are speculative and may be wildly inaccurate, but large-scale modifications to the rain forests - part of the engine room of global climate - are likely to provoke changes for better or worse that will be beyond man's power to control once they are set in motion.

Natural forests are rare in South African landscapes. One of the finest examples is the Afro-montane forest in the coastal belt near Knysna. This suffered massive destruction and as much as $80^{\circ}$ of it was cut down and replaced by farmland. Although few species had their survival threatened by this, immense populations were destroyed and with them great reservoirs of genetic diversity.

Animal extinctions

The question of the extinction of animal species by human interference, either by direct reduction of population size or by disturbance of ecosystems, has been considered by various authors during the last decades. Attention has in recent years again been focused on the possible accelerated disappearance rate of larger animal species as a result of human interference, and red book and black book lists have been prepared. The red data book names the species whose population size is so reduced that they are unlikely to persist unless special measures are taken to preserve them. The black data book names those species lost since 1600. These lists have been drawn up by the Survival Service Commission of the International Union for the Conservation of Nature and Natural Resources, which has its headquarters at Morges, Switzerland. The year 1600 was selected as the starting date for these lists because from that time descriptions of animals were usually adequate, especially in regard to colour, to permit a diagnosis of the taxonomic: entity to which they referred.

It is estimated that in 1600 there were 4226 living species of mammals, 36 of which $(0,85 \%)$ have now become extincl; $120\left(2,84^{\circ}\right)$ are in some danger of extinction. The corresponding figures for birds are 94 extinct out of 8684 species in $1600\left(1,09^{\circ}\right)$ and $187\left(2,16^{\circ}\right)$ are now threatened. An analysis of causal factors leading to the extinction or endangering of $-457-$ 
bird and mammal species since 1600 suggests that modern man, as exterminator, has at least six major methods at his disposal (and a seventh, chemical pollution, recently added): overkill; habitat destruction by logging, fire, introduced browsing and grazing animals, and draining; introduction of predators; introduction of competitors; introduction of diseases: and extinctions secondary to other extinctions. Because some 36 species of mammals and 94 species of birds have gone since 1600, the extinction rate is approaching 50 per century (Diamond, 1984). Hunting (overkill) and ecosystems disturbance (habitat destruction) between them have been responsible for over three quarters of the losses and reductions.

Overkill is the sole mechanism by which marine mammals have been exterminated and it has also been the main cause or a major cause in virtually all the forty-six modern extinctions of large terrestrial mammals (e.g. the quagga, the bontebok and Burchell's zebra in Africa), and in about 15 per cent of bird extinctions (e.g. great auk, passenger pigeon, dodo, and Arabean ostrich). Habitat destruction is now the most important cause of extinction, especially because of accelerated destruction of the species-rich tropical rain forests. During the past four centuries ecosystem disturbance is believed to have played the major role in about half of continental bird extinctions and about one-fifth of island bird extinctions.

Unfortunately South Africa still has many mammals, birds, reptiles (and plants) on the endangered list. The main reason for this is that their habitats have been so markedly altered by man that they can no longer survive. Conserving wildlife in a country such as South Africa where old traditions and attitudes die hard, is extremely difficult. The frontier spirit still burns strongly in many people and is reflected in extremely aggressive attitudes towards predators and scavengers.

The fauna - vertebrate and invertebrate - of Africa's subsaharan ecosystems stand at a crucial point in biogeographical history. The fate of the continent's wildlife now rests largely in the hands of the African people themselves. If certain practices and trends established in the colonial period that are still being followed continue very far into the future, the faunal map of Africa in relation to the larger mammals will $-458-$ 
include only the game parks and reserves. And, even that inay be too optimistic.

\section{Biological invasions}

The diffusion of life-forms beyond their natural area of occurrence is a significant aspect of ecosystem interference. Many introductions of alien species are made because they are a useful source of food, but other introductions have beer made to cuntrol existing pests or simply from curiosity to see how the newconer will cope with its new environment. Equally, many introductions have been accidental rather than deliberate. One thing is clear: the most violent eruptions of populations occur when a species is introduced into a new area wiere there are both unexploited resources and a lack of negative interactions. The population explosion of rabbits introduced into Australia is, of course, a well-known example among the thousands of cases of severe oscillations that result when species with high biotic potential are introduced into new areas.

In the book The ecology and management of biological invasions in southern Africa by Macdonald et al. (1986) the authors synthesized available information on the invasion of southern Africa's natural ecosystems by introduced organisms. Although most of the species that have become invasive come from other continents, there are some species which have been introduced from elsewhere in Africa. The ecosystem and peoples of southern Africa have suffered also major invasions by introduced pathogens; for example, the ecological systens of our tropical and subtropical regions still bear the imprints of the rinderpest outbreaks of 1896 and 1904.

The number of alien species and the nature and variety of their impact on many areas has now reached such levels that land managers are seriously concerned that invasive species as a whole vill become unmanageable. The southern African situation is unique in that we have both well developed and less developed econonics and land-use systems intermingled within the same region. This juxtaposition has resulted in a situation where a wide range of alien species are invading rangelands which do not contribute much to the cash econory of the region. Another 
example of the uniqueness of this region is that control programmes are currently being implemented, which integrate the latest advances in biological control with labour-intensive manual control operations, the extent of which would be inconceivable in a First World region. It is hoped that in many ways the southern African experience will bridge the gap between countries rich in expertise but with limited human resources, and the needs of those huge areas in the less developed world where expertise in biological invasions is virtually absent, but where alien invasions on the scale found in southern Africa have just begun (Macdonald et al., 1986).

\section{Desert encroachment}

One of the most contentious and important environmental issues of recent years has been the debate surrounding the question of the alleged expansion of deserts. Rapp (1974) defines desertization as the spread of desert-like conditions in arid or semi-arid areas, due to man's influence or to climatic change. It is evident that it is largely a combination of man's activities with occasional runs of dry years that leads to presently observed desert encroachment (Glantz, 1987). The process also seems to be fiercest not in desert interiors but on the less arid marginal areas around them. It is in the semi-arid areas, where biological productivity is much greater than in the extremely arid zones, where precipitation is frequent enough and intense enough to cause rapid erosion of unprotected soils, and where man is prone to mistake short-term economic gains under temporary favourable climatic conditions for long-term stability, that there is to be found the combination of circumstances particularly favourable to desert expansion (Goudie, 1981). It is in these areas that dry farming and cattle rearing can be a success in good years so that susceptible areas are ploughed and cattle numbers become greater than the vegetation can support in dry years.

Depletion of vegetation has, therefore, occurred which has set in train such insidious processes as water erosion and deflation. The vegetation has been removed by clearance for cultivation, by the cutting and uprooting of woody species for fuel, by overgrazing, and by burning of vegetation for pasture and charcoal. This also happened in many parts of southern Africa. Experiments as well as observations in natural con$-460-$ 
ditions tend to show that in certain specific circumstances rocovery is so slow and so limited that it may be appropriate to talk of irreversible desertization.

\section{CI.IMATE AND ATMOSPHERE}

With the increasing human population and the rising level of technology it is now apparent that over the last century man has probably become a significant factor in the variations in world climate which are taking place. Man can be considered a factor particularly because of his inadvertent effects on atmospheric quality and on the albedo (effect of reflectance or re-radiation of the solar radiation received, at the earth's surface) of land masses.

The $\mathrm{CO}_{2}$ problem

Excess carbon dioxide tends to be removed from the atmosphere by the oceans, but the process is slow and some buildup of carbon dioxide in the atmosphere has occurred since the beginning of the industrial era. Man has been taking stored carbon out of the earth in the form of coal, petroleum and natural gas, and burnt it to make carbon dioxide, heat, water vapour and smaller amounts of $\mathrm{SO}_{2}$ and other gasses. Carbon dioxide is largely transparent to the rays of the sun, but significantly opaque to the longer-wavelength thermal radiation which is emitted by the surface of the earth. Thus, if the atmospheric concentration of $\mathrm{CO}_{2}$ increases, the greenhouse effect theory posits that the income of solar radiation to the earth's surface will be but little altered, whereas the outgo of thermal radiation to space will be significantly reduced, providing a net energy gain for the earth-atmosphere system and a warming of the planet's surface (Maddos, 1983; Gribbin, 1986; Kerr, 1986; Pearce, 1986).

From a pre-industrial value of 260 to 270 parts per million ( $p p m$ ), the $\mathrm{CO}_{2}$ concentration of the atmosphere has now reached a value of about $350 \mathrm{ppm}$, and it is estimated that by the year 2065 a value of 600 ppm will be achieved. This fact of increasing atınospheric $\mathrm{CO}_{2}$, combined with the greenhouse theory has led to considerable concern in scientific circles. Evidence published in the USA during 1986 leaves little room for 
doubt that the greenhouse effect is now an established fact: carbon dioxide sent into the air whenever fossil fuels are burnt traps reflected heat from the earth's surface and prevents it from escaping into space - just as a greenhouse traps heat on a suminer's day. This effect could, within the next century, raise the world's temperatures to levels that have not been reached for 100000 years. And the effects on sea level and on agricultural and other human activities are likely to be so profound that we should be planning for them now. Industrialization is not the only cause of change in $\mathrm{CO}_{2}$ levels. Changes in land-use, especially deforestation and agricultural expansion, have reduced the overall quantity of plant biomass, thereby releasing large amounts of $\mathrm{CO}_{2}$ into the atmosphere.

It is difficult to assess the consequences of temperature increases which can occur as a result of higher $\mathrm{CO}_{2}$ levels. On the bonus side growing seasons in the world's cereal-growing lands would be increased, but on the debit side is the possibility that the extent of deserts might expand and that sea levels might rise a few metres to flood coastal areas as a result of the partial melting of ice caps and glaciers. If temperatures do rise by $1,5-3^{\circ} \mathrm{C}$ then we shall have conditions similar to those that existed during the warmest phases of the Holocene (the hypsithermal) and to those of the warmest portions of earlier Pleistocene interglacials (Goudie, 1981).

Ozone depletion and creation

The stratospheric ozone layer shields the surface of the earth from ultraviolet sunlight, preventing excessive sunburn, skin cancer, and cellular and subcellular damage in people, animals and plants. A number of man-made processes have been postulated that could affect this layer and quantitative estimates have been made of the resulting depletion (Butler, 1978); these processes include supersonic aircraft emissions, chlorofluoromethanes (CFMs) from aerosol spray cans and refrigerants, nitrous oxide from fertilizers and nuclear bomb debris. The CFMs, like $\mathrm{CO}_{2}$ also prevent some of the infra-red terrestrial radiation from the surface, that would otherwise escape to space, from passing through the lower atmosphere, thereby leading to an increase in the surface temperature. 
Unlike the protective shield of ozone high in the stratosphere, ozone at ground level could be dangerous. For several days during most summers, Europe and other industrialized parts of the world are bathed in ozone at concentrations that would be illegal if created in a factory (Pearce \& Elsworth, 1986). It is created by sunlight acting on a range of pollutants, especially from car exhausts. The ozone causes attacks of asthina in humans, eats at every kind of material froin rubber bands and car tyres to textiles, stunts the growth of plants and may be an important cause of the decline of trees in certain areas. Ozone is a more serious problem in Europe than anywhere else on earth, apart from the Los Angeles basin in the USA where ozone smog were first discovered. But the problem is global. In the past 40 years, the number of cars in the world has increased from 38 million to 350 million.

Apart from sunlight, the formation of ozone requires nitrogen oxides and any of a range of hydrocarbons. Alkanes and alkenes react most quickly and have the biggest effect in creating ozone simogs. The chemical reactions involved in the process are immensely complicated. Recently a computerized model of ozone formation was completed that includes several hundred reactions and requires a Cray computer to make sense of it. Car exhausts are probably responsible for two-thirds of the ozone generated. There is a complication, however. Cars produce nitric oxide, which is oxidised in the air to nitrogen dioxide. Only then can it take part in the formation of ozone. One effect of this is that in the centre of big cities, ozone levels can be quite low - because of the scavenging effect. Meanwhile, in the surrounding countryside, where there is little nitric oxide left to destroy ozone, levels soar. Another effect is that controlling nitric oxide emissions on their own could, in city centres, actually increase the amount of ozone present. The obvious solution is to require all new cars to be fitted with catalytic converters.

Acid rain

In the 1950's observers noticed an increase in the acidity of water in lakes in various parts of the world. By 1959 Norwegians had established a connection between the increase in acidity and a decline in fish populations. Presently there are many lakes in the world with no fish and if this trend continues, life in thousands of lakes could disappear in 10 
to 20 years. These effects are attributed to acid rain (Purdom \& Anderson, 1983). The primary cause of acid rain is the burning of fossil fuels in electric generating stations and industrial boilers. Sulphur in fuel is converted to sulphur-oxides (mainly $\mathrm{SO}_{2}$ ) when burned. Oxides of nitrogen (mainly NO) are produced by stationary (568) and mobile (40\%) combustion sources. In the atmosphere, these substances are transformed (oxidized), particularly in the presence of sunlight, to sulphate and nitrate aerosols. If moisture (in the form of rain, snow, dew, or mist) is present, sulphuric and nitric acids are formed. The acid particles can be deposited dry or fall with precipitation.

The anount of time sulphur dioxide hangs in the atmosphere has been found to range from 15 to 30 hours in the cold season and 15 to 40 hours in the warm season. However, $\mathrm{SO}_{2}$ converts rapidly to sulphates, and the residence time of sulphates is 150 to 400 hours in cold season and 200 to 400 hours in warm. The first victims of acid rain are eggs of amphibians and fish. As lakes become more acid, bacteria disappear, frogs die, and leaves and other litter pile up on the lake bottom. Normal rain around the world has a $\mathrm{pH}$ of 5,6 . Below $5,5 \mathrm{pH}$, traditional plants are replaced by mosses, fungi and algae. Adult fish are probably the last to die.

Scandinavia is particularly sensitive to acid rain for two reasons: orographic precipitation and podsol soils. Rain is often triggered by lifting of air masses over the high ground of Scandinavia, delivering pollution in high concentrations to small target areas. The soils and lakes of Scandinavia have low buffering capacities and so are sensitive to slight changes in acidity. In areas suffering from salinization, on the other hand, acid rains would be beneficial. In recent years, the concern about acid rains has spread to North America and to some podsolized regions in the tropical rain forests. There are in fact increasing numbers of international research and monitoring activities as well as international meetings dealing with these questions.

\section{WATER QUALITY}

In any ecosystem, water is essentially the vehicle through which recycling of nutrients is achieved. Water is in any case necessary in some form -464 - 
or another for the continued existence of most producer, consumer and reducer populations, but it is especially with respect to this recycling process that the water transport of essential substances is most critical for the continued functioning of a given ecosystein. The two water soluble substances most critical in these recycling processes are nitrates and phosphates, both of which are limiting to the productivity of most natural ecosystems. Any disturbance of the process of recycling dissolved nitrates and phosphates through an ecosystem will therefore generally have most critical effects on it. Decomposer populations in aquatic ecosystems usually release the more soluble nitrates quicker than the less soluble phosphates. This is readily observable in dam and lake ecosystems.

Lakes and reservoirs are not permanent features of the landscape. Geologically speaking, they are only water-filled natural or man-made depressions in the earth's crust that are destined to become filled with: soil and organic deposits as time passes. Fundamentally they are giant sedimentation basins which not only serve to remove suspended matter from tributary waters but also act as giant reaction vessels for biological phenomena involving production of both plants and animals. From a stric: conservationist viewpoint, the function of lakes is to retain on the land areas of the world those matters of value to the land and to prevent their being carried to the oceans (Sawyer, 1969).

The construction of dains and reservoirs increased markedly especially between 1945 and 1971. The impact of man's activities regarding the stable runoff which is regulated by water reservoirs in the continents of the world is especially marked in Africa and North America; about 208 of the total runoff is now regulated by them. One of the most apparent features of man-made dams and reservoirs is that they are becoming increasingly large. Such large dams are capable of causing almost total regulation of the streams they impound, but in general the degree to which peak flows are reduced depends on the size of the dam and the impounded lake in relation to catchment characteristics.

Most dams achieve their aim: to regulate river discharge, and they have been highly successful in achieving what they were constructed for; millions of people depend upon them for survival, welfare, and employ-465- 
ment. However, dams may have a whole series of environmental consequences that may of may not have been anticipated. Certain of these consequences may in turn affect the viability of the scheme for which the dam was created.

A particularly important consequence of the impoundment of a reservoir behind a dam is the reduction in the sediment load of the river downstream. Sediment retention in dams is well illustrated by the Nile both before and after the construction of the great Aswan High Dam. Until its construction the late summer and autumn period of high flow was characterized by high silt concentrations, but since it has been finished the silt load is rendered lower through the year as a whole and the seasonal peak is removed. This sediment removal in turn has various consequences, including a reduction in flood deposited nutrients on fields, less nutrients for fish in the south-east Mediterranean Sea, accelerated riverbed erosion because less sediment is available to cause bed aggradation - so-called clear-water-erosion (Beckinsale, 1972).

Pollution

The introduction of large quantities of nitrogen and phosphorus into water bodies is one of the major problems of wastes today. Phospliorus is a scarce element in the lithosphere and many ecosystems are adjusted to its scarcity: it is a limiting factor. The large quantities made available by human-induced concentrations lift such limits and 'blooms' result; nitrogen may then become the limiting factor and organisms such as blue-green algae take over from the plankton because they escape the nitrogen limits. Blooms of such algae then follow. The additional nitrogen and phosphorus accelerate the ageing of lakes and dams by nutrient enrichment or eutrophication. Such a process happens naturally but is speeded up many times by human activities which result in large inputs of phosphorus and nitrogen. The cessation of eutrophication of water bodies is clearly an immense task and failure to achieve it will result in the loss not only of biologically significant elements of diversity but also in the diminution of an important element of environmental quality for humans (Simmons, 1974). 
Rivers, streams and dams may be polluted by domestic pollution, soil pollution, industrial pollution and heat (thermal) pollution. The animals which live in fresl, water are mostly intolerant of a reduced oxygen supply. Organic waste products decompose in the water and it is the oxygen demand of the decomposer organisins which causes the low concentration of dissolved oxygen where there is too much organic matter. The decomposers - mainly bacteria and fungi - involved in the decay use oxygen, and thus reduce the amount avalable for the freshwater animals. Types of pollutants include sewage and other organic wastes (such as wood fibres from paper mills; pathogens (mostly bacteria and virusses) from human wastes; toxic materials such as mercury, pesticides and petroleum; and chemicals (usually phosphorous or nitrogen). The addition of waste heat to water is mainly from electrical generating plants, both conventional and nuclear. The eventual solutions to the problems of organic and thermal pollution should be aimed at using the organic materials (to enrich soil, for example) and the waste heat, rather than simply trying to dissipate them (Brewer, 1979).

The oceans

Seven-tenths of the earth's surface are ocean and these water bodies are important in controlling global energy flows. A major difficulty in assessing human impact on the oceans is presented by the huge scale and slow response rate of these great water bodies. The length of time involved and the possible transmutations of the chain of cause and effect make it very difficult to understand how man's actions affect the workings of the oceanic environment, and this is particularly true of the effects of pollution. The oceans are the global dustbin but they are not a bottomless sink, however, any more than they are an endless source of food. Although they are a vast energy store, the energy is thinly distributed throughout the oceans, and this may mean that they are a fragile ecosystem.

The frequent oil spillages at sea are spectacular and receive considerable publicity when they are sufficiently large and damaging. An estimated six million tons of petroleum hydrocarbons reach the oceans annually (90 per cent of them due to man). It is thought that thin oil layers may concentrate trace pollutants such as heavy inetals, DDT and amino acids. 
It is these chronic, low concentration pollutants rather than oil itself that may eventually have the most marked effects on the workings of the oceans.

The story of man and the oceans is an inconclusive one; we do not know whether even the present levels of pollution or fishing are sufficient to cause significant changes in the oceans. Similarly, the thresholds and leverage points are uncertain. However, the smaller, enclosed seas e.g. the Baltic, Black and Mediterranean seas - in the developed world unmistakably show the effects of man's actions (Drew, 1983).

\section{PESTICIDES}

A pesticide is a chemical which will attack and kill a pest, for instance, insecticides which are designed to kill insect pests. There have always been animal pests of food crops, with heavy losses caused by their activities, both while the crop was growing and when it was stored after harvest. Large scale manufacture and use of pesticides began around the middel of this century. In the time before agriculture as we now recognise it, pest populations were at a low level. The animals would hardly be pests as the natural complexity of the ecosystem did not allow huge populations to build up. In natural communities most species of animals do and did not reach the abundance they could reach feeding on crops. Then, as more food become available, higher populations of pests were possible on crop plants. But the environment was simple, and it was easy for a population to crash; the population curve of a pest therefore fluctuated.

When pesticides were used the population fluctuations became larger because the environment was even simpler. Natural enemies of the pest, as well as the pest itself, were removed by the pesticide. Without its predators, the pest could then build up a bigger population later from individuals which had escaped the toxin, or had immigrated from another area. Following the appearance of pest strain resistent to pesticides, pest populations could become even larger.

DDT is one of the best known, and longest used insecticides. It was first used on a massive scale about the mid-1940's. It and its effects $-468-$ 
have been thoroughly studied, and its ecology is now well known. As a killer of insects DDT is extremely effective. It is used to reduce the number of malaria-carrying mosquitoes. As a result millions of lives have been saved. There are now about 120 million cases of malaria per year throughout the world, as compared with 300 million cases $(3$ million deaths) per year before 1946 (Sands, 1985). Anti-malaria campaigns are now the major consumers of pesticides. Twenty seven thousand tons of DDT are used each year, plus about 3000 tons of other pesticides.

When DDT was first introduced in Sri Lanka, the adult death rate fell by $66 \%$, and malaria was completely eradicated from the island. But DDT also markedly reduced the incidence of other insect-carried diseases such as typhus, yellow fever, sleeping sickness and river blindness. Besides combating human diseases, DDT also played an important role in killing insect pests of crops; this greatly increases the yield of marketable produce and, in addition, the vegetables and fruit look better with no insects and no insect damage.

On the other hand, DDT has other properties or side effects, which have caused it to be banned - also in the RSA - from widespread and indiscriminate use. In some cases the use of insecticides has gone wrong where useful animals such as bees which pollinate fruit trees and crops have also been killed. In other cases the pest increased enormously the year after spraying because of the reduction of natural predators and parasites, e.g., the natural enemies of the codling moth and the red spider mite in the orchards of the Western Province; they were either also killed by the insecticide, or else they depended on the density of their prey to keep up their numbers. Sometimes reducing the numbers of a particular pest has caused another, more resistant, pest to increase. Also, an important aspect is that strains of many insects resistant to specific pesticides have evolved.

DDT accumulates at successive steps in a food chain - biological concentration - and residues are found in all foods used by humans. Evidence shows that DDT reduces the reproductive rate of birds to a level which could cause the extinction of rare species. The long-term effect of DDT on animals or man is actually not known. It is very resistant $-469-$ 
to decomposition and stays in the soil as a poisonous substance for many years. DDT is found in the fat of organisms over probably the whole world, including places where no DDT has ever been used; penguins in Antarctica, for example, had DDT levels up to 18 parts per million in 1964-65.

The fact that some environmental factors (e.g. temperature and humidity) act more strongly in combination than would be suspected from their ef fects singly, is also true of certain pesticides: Malathion is considered a relatively safe pesticide because it is rapidly detoxified by the liver; however, some chemical which interfered with the detoxification function of the liver would increase the danger of malathion poisoning. Just such a chemical is another pesticide, EPN. Malathion was made 50 times more poisonous to dogs when EPN was given at the same time (Brewer, 1979). There are a great many man-made chemicals in use - half a million according to the editors of The Ecologist - in pesticides, food additives, hair sprays, medicines, paints, fuel additives, and many other things. The change of unsuspected synergistic effects increases as the number of such chemicals increases.

Many tens of thousands of farm workers die every year around the world from poisining by pesticides (Pearce, 1987b). In a major rice-growing area of the Philippines, the introduction of insecticides coincides with an increase in the death rate of more than a quarter among men in the villages. The "green revolution" in Asia has for the first time put hundreds of millions of farm workers in daily contact with dangerous chemicals. Between 1970 and 1974, local purchases in the Philippines rose by more than 250 per cent. Compounds included carbofuran, endrin and parathion, all classified by the World Health Organization either as extremely or highly dangerous. Farmers spray the pesticides onto their crops from backpacks - usually without protective clothing. Endrin falls in a class of insecticides which can poison the central nervous system and produce symptoms similar to a stroke. Until 1976, most men died in August, the height of the spraying season. After 1976, an irrigation project allowed a second planting and spraying season in February and a second peak in deaths quickly emerged in that month. Endrin was banned from Philippine fields in 1982 and the death rate from strokes among men reverted to past levels. 


\section{MAN'S ROLE IN NATURE}

Man sees the world around him through the spectacles of culture and nature is thus transformed into resources. We are far from being the first civilisation to realise that our environment is at risk. Most tribal environments are held to be in danger in much the same way as ours, but, unlike tribal society, we have the chance of self-awareness. Time will reveal whether - according to the gloomy forecasts of some authors - the earth will be burnt up by the unbalancing of its radiation budget, or whether a film of dust will blarik out the sun's rays, or whether it will explode in an atomic war.

Environmental protection

In 1962 Rachel Carson's book Silent spring produced a wide public awakening on the nature and consequences of environmental pollution. Existing conservation orgarizations and new groups became active participants in environmental concerns. A significant event of this environmental movement was the UN Conference on the human environment (1972) in Helsinki, and the creation of the United Nations Environmental Program (UNEP) with headquarters in Nairobi, Kenya. In South Africa symposia were held on the habitat and on biological research and problems of the environment in 1972. A white paper on a National Policy regarding environmental conservation was published in 1980 and a report by a commission of inquiry into environmental legislation was tabled in Parliament in 1981. The Environment Conservation Act 100 of 1982 is regarded as the most important conservation measure to be adopted in South Africa.

Environmental protection has three objectives (Parker, 1980). The first is to protect people from physiological damage from pathogenic organisms, from toxic chemicals, and from excesses of physical energies. The second is to spare humans annoyance, irritation, and discomfort from offensive conditions in water, in air, and on the land. The third objective is to safeguard the balances in the earth's ecosystems and to conserve natural ressurces.

Conservation receives impetus from the social conscience being aware of an cbligation to future generations but it is viewed differently according -471. 
to one's social and economic philosophy. It deals with the judicious development and manner of use of natural resources of all kinds. It is the protection of nature from commercial exploitation to prolong its use for every living being on earth. It also involves the correction - or restoration - of past willful and inadvertent abuses that have impaired the productivity of the resources base. Substitution is also an important conservation measure: The use of a common resource instead of a rare one when it serves the same end, and the use of renewable rather than non renewable resources when conditions permit.

Although it is technologically based, conservation cannot escape the socially determined values. There is an ethic involved in all aspects of conservation. Certain values are accepted in conservation, but they are the creation of society, not of conservation.

Environmental ethics

Part of man's seemingly infinite capacity to rationalise is his ability to fix blame, preferably on people or forces beyond his control. Some observers have sought an explanation for the exploitative attitude that has prompted much environmental modification in the Western World in the teachings of the Judaeo-Christian religious tradition. White (1967) and Toynbee (1972) theorised that this ethic was the cause of western man's alienation from nature, his objectification of natural objects and processes, his anthropomorphism, and his quest for progress at all costs. He maintains that the source of our ecological problems is to be found in the belief that mankind was created to have dominion over nature, a belief which according to his theory, can be interpreted as implying that humans may treat their natural environment as they like. White's article sparked off a lively debate over the role of Judaeo-Christian teaching in determining environmental cognition (Moncrief, 1970; Black 1970; Elder, 1970; Fackre, 1971; Barbour, 1972; Steffenson et al., 1973; Boughey, 1975; O'Riordan, 1976; Passmore, 1980; Attfield, 1983), especially with reference to Genesis 1:26-28.

"And God said, let us make man in our image, after our likeness: ano let him have dominion over the fish of the sea and over the fowl of the air, and over the cattle and over all the earth and over every creeping $-472-$ 
thing that creepeth upon the earth. So God created man in his ovir. image, in the image of God he created him: male and female created ho them. And God blessed them and God said unto them. Be fruitful and multiply and replenish the earth and subdue it: and have dominion over the fish of the sea, and over the fowl of the air and over every living thing that moveth upon the earth."

White's article has, as Passmore (1980) observes, exercised widespread influence, partly because of the delayed but increasing impact of Aldo Leopold's (1966) call for a new ethic. White's view that technology, the immediate cause of some of our ecological problems, cannot be expected to solve them alone, commands wide agreement, but there is less agreement about the nature and extent of the other social and moral changes required (Attfield, 1983). Moncrief (1970), for instance, suggested that White's simplistic "religious" explanation is based more on fad than on fact, and he pointed out that the environmental crisis appears to have a cultural basis in being directly related to forces of technology, urbanization, increasing individual wealth and an aggressive attitude towards nature. The connection between all this and the Judaeo-Christian tradition is, according to Moncrief, at most that this tradition may have encouraged capitalism and democracy, but the empirical evidence for this is slender. The belief that nature may properly be used by mankind does not justify an ilresponsible attitude to nature; the biblical dominion of man is no despotism. On the other hand, a belief in the sacredness of nature makes medical and scientific research not only wrong but actually impious, and this ban would include the science of ecology itself; against such a view Christian defenders of science have quite properly appealed to the Bible.

The Judaeo-Christian tradition has historically stressed responsibility for nature - and that not only in the interest of human beings - and if its secular critics have often echoed this emphasis, then whatever the causes of the problems may be, our traditions offer resources which may, in refurbished form, allow us to cope with these problems without resorting to the dubious and implausible expedient of introducing a new environment ethic (Attfield, 1983). The idea that each generation of men are stewards of the earth who hold it for only a limited period and who are $-473-$ 
obliged to account for their tenure is basically a theistic idea. Black (1970) traces the notion of stewardship in the Judaic and Christian scriptures and finds numerous examples of the concept of a man who is merely a temporary guardian of a resource and who is expected not merely to protect it against harm but to enhance its value. Boulding (1971) also maintains that a shift in ethics towards man as a steward is a necessary part of the reconciliation between ecological an economic imperatives. A more specifically Christian formulation of similar principles is given by Montefiore (1970).

In the first extended philosophical treatment of ecological problems Passmore (1980) examines Western moral traditions and historical attitudes to nature, and in the course of his subsequent survey of the problems of pollution, resources, population growth and preservation defends the view that no new ethic is needed to cope with the problems, so long as the traditional belief that man has dominion over nature and that people may manipulate their natural environment in their own interests is interpreted in a suitable humble way. Passmore also mentions the traditions of stewardship and cooperation with nature, the latter embodying the view that mankind should endeavour to develop and perfect the natural world in accordance with its potentials; stewardship involves the belief that people are entrusted with a duty to preserve the earth's beauty and fruitfulness. Calvin, for instance, explicitly resuscitated the New Testament metaphor of stewardship, which he applied both to a person's possessions and to the care of the earth as a whole, decrying the 'plundering of the earth of what God has given it for the nourishment of man' as frustrating God's goodness (Derr, 1973). The stewardship idea is analysed by Black (1970), who remarks that in the Biblical times the steward had the duel role of managing the estate for profit while also ensuring its long term viability. This idea also forms part of Riddell's (1981) ecodevelopment concept: "Improving the quality and variety of life is a common goal - achieved through the distribution of increased purchasing power earned from conventional development coupled to the provision of a healthy habitat through environmental management; the latter implies a concept of stewardship wherein mankind has a duty, beyond immediate interests of establishing societal responsibilities within national ecosystems". 
It is clear that whatever has caused our ecological problems, they cannot be set down to Judaeo-Christian attitudes to nature. This was also explicidly pointed out in the excellent book of Fuggle \& Rabie (1983) Environmental concerns in South Africa. In the Preface they state: "Although the book stems directly from our personal and professional interests in environmental conservation it also reflects our Christian commitment and understanding of man as a steward in a world belonging to God. It is our belief that developments in environmental conservation must take place in ethical and moral realms just as inuch as in ecological and technical fields and we hope that this book will lead the reader tc this conclusion". In the section on the ethics of environmental conservation the authors write the following: "Judaeo-Christian ethical norms require inan to recognize that subhuman nature has a right to exist over and above its utility to man. They hold that man has been given control and management of the environment only to meet his needs and that it is man's responsibility to ensure that natural processes are sustained anc: that natural phenomena are not destroyed. Judaeo-Christian belief is that although both man and nature are created by God the relationship between them is no longer perfect because of Inan's sin. Christian belief is that it is through Jesus Christ that man will be reconciled with nature, fellow man, and God. This echoes a commonly theme in modern studies of environmental problems, namely that their solutions lie not so much in technological or scientific advance, but in awakening an awareness of the non-material dimension in man-environment relationships".

The concept of the ecological conscience which is regarded as one of the most important moral discoveries of our time, arose out of the thinking and writing of Aldo Leopold and Albert Schweitzer. The credo of Schweitzer has been put in these words: "A man is ethical only when life as such is sacred to him, that of plants and animals as well as that of his fellow man" (Robertson in Habitat RSA). Improving the environment should not mean only correcting pollution or the other evils of technological and urban growth. It should be a creative process through which man and nature continue to evolve in harmony. At its highest level, civilized life is a form of exploration which helps man rediscover his unity with nature.

\section{BIBLIOGRAPHY}


ATTFIELD, R. 1983. The ethics of environmental concern. Oxford: Blackwell.

BAKER, G., ed. 1976. Resources of Southern Africa - today and tomorrow. AS \& TS : Johannesburg.

BARBOUR, 1.G., ed. 1972. Earth might be fair: Reflections on ethics, religion and ecology. Englewood Cliffs, N.J : Prentice-Hall.

BECKINSALE, R.P. 1972. The effect upon river channels of sudden changes in sediment load. Acta Geographica Debrecina, 10:181-186.

BENNETT, C.F. 1975. Man and earth's ecosystems. London : Wiley.

BLACK, J.N. 1970. The dominion of man: The search for ecological responsibility. Edinburgh : John Black.

BOUGHEY, A.S. 1975. Man and the environment. New York : MacMillan.

BOULDING, H.K. 1971. Environment and economics. (In Murdock, W.W., ed. Environment. Stamford : Sinaver, p.359-367.)

BOURKE, G. 1987. Forests in the Ivory Coast face extinction. New Scientist, June 11:22.

BREWER, R. 1979. Principles of ecology. Philadelphia : Saunders.

BROWN, L. E FINSTERBUSCH, G. 1971. Man, food and environment. (In Murdoch, W.W., ed. Environment Stamford: Sinauer, p.53-70.)

BUTLER, G.C., ed. 1978. Principles of ecotoxicology. Chichester : Wiley.

CARTER, L.J. 1977. Soil erosion: the problem persists despite the billions spent on it. Science 196:409-411.

COFFEY, M. 1978. The dust storms. Nat. Hist. (NY), 87:72-83.

$-476-$ 
DERR, T.S. 1973. Ecology and human liberation. Geneva : WSCF Books.

DIAMOND, J.M. 1984. Historic extinctions: A Rosetta stone for understanding prehistoric extinctions. (In Martin, P.S. E Klein, R.G., eds. Quarternary extinctions. Tucson : Univ. Arizona press, p. 824-862.)

DICKSON, D. 1978. Brazil learns its ecological lessons - the hard way. Nature, 275:684-685.

DREW, D. 1983. Man-environment processes. London : Allen and Unwin.

ELDER, J. 1970. Crisis in Eden: A religious study of man and environment. New York : Abingdon Press.

FACKRE, G. 1971. Ecology and theology. Religion in life, 40: 210-224.

FLENLEY, J.R. 1979. The equatorial rain forest: a geological history. London: Butterworth.

FUGGLE, R.F. 1983. Population growth and resource demands (In Fuggle, R.F. E Rabie, M.A., eds. Environmental concerns in South Africa. Cape Town : Juta, P.23-29.)

FUGGLE, R.F. \& RABIE, M.A., eds. 1983. Environinental concerns in South Africa. Cape Town : Juta.

GEERTS, C. 1963. Agricultural involution: the process of ecological change in Indonesia. Berkeley: Univ. Calif. Press.

GLANTZ, M.H. 1987. Drought in Africa. Scientific American, $256(6): 33-10$.

GORTZ, A. 1980. Ecology as politics. Boston : South End Press. 
GOUDIE, A. 1981. The human impact. Man's role in environmental change. London: Blackwell.

GRIBBIN, J. 1986. Temperature rise in the global greenhouse. New Scientist, 15:32-33. May.

HALL, A.V. \& RABIE, M.A. 1983. Indigenous plants (In Fuggle, R.F. E Rabie, M.A., eds. Environmental concerns in South Africa. Cape Town : Juta, p.164-189.)

HUGO, F.J.C. \& VAN SCHALKWYK, C.J. 1987. Landbou-ontwikkeling en die natuur. (In Wèreld-ongewingsdagsimposium: Die omgewing: Natuur en die beskawing in konflik?)

KERR, R.A. 1986. Greenhouse warming still coming. Science, $232: 573-574$.

LEOPOLD, A. 1966. A Sand County Almanac with other essays on conservation. New York : Oxford Univ. Press.

MADDOX, J. 1983. Great greenhouse in the sky? Nature, 306:221.

MIKESELL, M.W. 1969. The deforestation of Mount Lebanon. Geographical Review, 59:1-28.

MONCRIEF, L.W. 1970. The cultural basis for out environmental crisis. Science 170:508-512.

MONTEFIORE, H. 1970. Can man survive? London: Fontana.

ODUM, E.P. 1971. Fundamentais of ecology. Philadelphia : Saunders.

O'RIORDAN, T. 1976. Environmentalism. London : Pion.

PARK, C.C. 1981. Ecology and environmental management. London : Butterworths. 
PARKER, S.P., ed. 1980. McGraw-Hill encyclopedia of environmental science. New York : McGraw-Hill.

PASSMORE, J. 1980. Man's responsibility for nature. London : Duckworth.

PEARCE, E. \& ELSWORTH, S. 1986. Stalled in a haze of ozone. New Scientist Nov. 20:18-19.

PEARCE, F. 1986. How to stop the greenhouse effect. New Scientist, 18:29. Sept.

PEARCE, F. 1987a. Banishing the salt of the earth. New Scientist, $11: 53-56$. June.

PEARCE, F. 1987b. Pesticide deaths: the price of the green revolution. New Scientist, 18:30. June.

PIMENTEl, D., hURD, L.E., BELlotTI, A.C., FORSTER, M.J., OKA, I.N., SHOLES, O.D. \& WHITMAN, R.J. 1973. Food production and the energy crisis. Science, 182:443-449.

POORE, M.E.D. 1976. The values of tropical moist forest ecosystems. Unasylva, 28:127-143.

POWER, J.F. \& FOLLET, R.F. 1987. Monoculture. Scientific American, 256(3): $57-64$.

PURDOM, P.W. \& ANDERSON, S.H. 1983. Environmental science. London : Merrill.

MACDONALD, I.A.W., KRUGER, F.J. E FERRAR, A.A. 1986. The ecology and management of biological invasions in southern Africa. Cape Town : Oxford Univ. Press.

RABIE, M.A. \& THERON, C.H.B. 1983. Soil (In Fuggle, R.F. \& Rabie, M.A., eds. Environmental concerns in South Africa. Cape Town : Juta, P. 142-163.) 
RAPP, A. 1974. A review of desertization in Africa - water, vegetation and man. Secretariat for International Ecology, Stockholm, Report 1.

RAPP, A., MURRAY-RUST, D.H., CHRISTANSSON, C. $\varepsilon$ BERRY, L. 1972. Soil erosion and sedimentation in four catchments near Dodoma, Tanzania. Geogr. Annaler, 54A:255-318.

RIDDELL, R. 1981. Ecodevelopment. Westmead: Gower.

SANDS, M.K. 1985. Problems in ecology. Sutton : Bell and Hyman.

SAWYER, C.N. 1969. Basic concepts of eutrophication (In Cox, G.W., ed., Readings in conservation ecology. New York : AppletonCentury-Crofts, p.462-472.)

SCHOEMAN, J.L. E SCOTNEY, D.M. 1987. Agricultural potential as determined by soil, terrain and climate. S.A.J. Sci., 83:260-268.

SIMMONS, I.G. 1974. The ecology of natural resources. London : Arnold.

SIMON, J.L. 1986. Disappearing species, deforestation and data. New Scientist, 15:60-63. May.

STEFFENSON, D.I., HERRSCHER, W.J. \& COOK, R.S. eds. 1973. Ethics for environment: Three religious strategies. Green Bay : Univ. Wisconsin Ecumenial Center.

TOYNBEE, A. 1972. The religious background to the present environmental crisis. Int. J. Environ. Studies 3:141-146.

WHITE, L. 1967. The historical roots of our ecologic crisis. Science, 155: $1203-1207$. 